\title{
Obituaries
}

Obituaries should be submitted by email to Laura Pacey at I.pacey@nature.com.

All submitted obituaries should be 350 words maximum in length (apart from obituaries for past presidents of the BDA where the length should be $700-800$ words).

Content of the obituary is down to the individual author, and the approval of the family should be given for the obituary prior

to submission to the $B D J$.

\section{MARTIN LEVY}

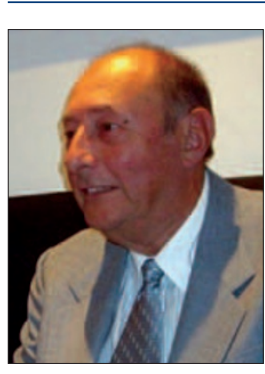

It is with profound sadness that I announce the passing of Martin Levy on 9 November 2012. He fought renal cancer just as hard as he fought the NHS, with a clear and articulate mind and a sense of humour. Martin was born on 7 January 1930. He studied at Owen's School, Islington and Bedford. He graduated with a BDS from University College Hospital Dental School and went on to obtain his LDS and RCS, both in 1954. He did his National Service in the RAF stationed at Benson in Oxfordshire and was dental surgeon to the Queen's Flight from 1954-1956, following which he set up practice in Stoke Newington, a deprived area, working there from 1957-1997.

Martin was a tireless fighter for his profession, working hard to ensure equity and parity for his colleagues, especially in inner city deprived areas. He held many offices within the profession both locally and at a national level through which he was instrumental in raising the status of London dentists. He was a member of the BDA's Representative Board, the GDSC, Dental Rates Study Group, Oral Appeals Tribunal, GDPA Council and its Policy Committee. For several years he wrote and presented the GDPA's evidence to the Doctors' and Dentists' Remuneration Body (DDRB). He was Vice Chairman of the Federation of London Dental Committee of LDCs and inaugurated and chaired the London Council of the BDA.
Martin fought successfully for the honorary title of 'doctor' for dentists as acknowledged in Dame Margaret Seward's recent book Open wide. His interests outside dentistry varied from being a collector of British Victorian period oil paintings to being a co-author of Encyclopaedia of model railways, with time to enjoy golf and bowls.

In 1959 he married Jean, an active charitable worker for Meals on Wheels and League of Jewish Women as well as helping Martin in his dental practice. He leaves behind his wife and two sons Graham Simon Levy and Clifford Philip Levy, both solicitors of high international standing.

Martin, one of our leading lights, though missed, will never be forgotten. The profession has lost one of its true warriors.

Amolak Singh

\section{RALPH GRUNDY}

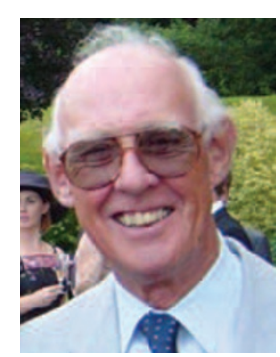

Many generations of dentists, including the writers of this obituary, owe much to the inspirational teaching of Ralph Grundy during their undergraduate years.

Ralph who died in August 2012 was born in 1928 and went to Bury Grammar School where his leadership skills showed early promise as Captain of School. In 1945, Birmingham Dental School was to become his home for undergraduate training and after a couple of years in the RADC and then general practice, Ralph chose to pursue a career in academia. This proved fortuitous for the profession as he was instrumental in pioneering new techniques in teaching, identifying the hazards of the air turbine spray and introducing innovative changes to the dental curriculum.

In 1953 Ralph secured a lecturership at The London Hospital in the conservation department before moving on after five years to Manchester from where he was later to receive the MDS degree by research. Ralph returned to his alma mater in 1961 as senior lecturer and consultant from where he retired after 30 years dedicated service to the school, university and patients. He was highly respected by his peers and became President of the British Society for Restorative Dentistry in 1980 and also held numerous external examinerships.

After retiring to Poole in 1991, Ralph with his wife Margaret, a colleague and distinguished consultant in paediatric dentistry at Birmingham Dental School, continued to indulge in their passion of sailing and extending hospitality to their many friends and former colleagues.

Sympathy is extended to his wife and family who can be reassured that the contribution to dentistry of this modest gentleman will be long remembered.

Robin Basker and Margaret Seward 